\title{
Induction of Oxidative Stress in Male Rats Subchronically Exposed to Electromagnetic Fields at Non-Thermal Intensities
}

\author{
Albert Achudume ${ }^{1}$, Bill Onibere ${ }^{1}$, Funso Aina ${ }^{1}$, Paschal Tchokossa ${ }^{2}$ \\ ${ }^{1}$ Institute of Ecology and Environmental Studies, Obafemi Awolowo University, Ile-Ife, Nigeria; ${ }^{2}$ Department of Physic and Radia- \\ tion, Obafemi Awolowo University, Ile-Ife, Nigeria. \\ Email: \{aachudume, jedii2000, funsoaina2002, ptchoko\}@yahoo.com
}

Received February $16^{\text {th }}, 2010$; revised May $14^{\text {th }}, 2010$; accepted May $21^{\text {st }}, 2010$.

\begin{abstract}
To investigate the oxidative stress-inducing potential of non-thermal electromagnetic fields in rats. Male Wister rats were exposed to electrical field intensity of $2.3 \pm 0.82 \mu \mathrm{V} / \mathrm{m}$. Exposure was in three forms: continuous waves, or modulated at $900 \mathrm{MHz}$ or modulated GSM-nonDTX. The radio frequency radiation (RFR) was $1800 \mathrm{MHz}$, specific absorption radiation $(S A R)(0.95-3.9 \mathrm{~W} / \mathrm{kg})$ for 40 and/or 60 days continuously. Control animals were located $>300 \mathrm{~m}$ from base station, while sham control animals were located in a similar environmental conditions, but in the vicinity of a non-functional base station. The rats were assessed for thiobarbituric and reactive species (TBARS), reduced glutathione (GSH) content, catalase activity, glutathione reductase (GR) and glucose residue after 40 and 60 days of exposure. At 40 days, electromagnetic radiation failed to induce any significant alterations. However, at 60 days of exposure various attributes evaluated decreased. The respective decreases in both nicotinamide adenine dinucleotide phosphate (NADPH) and Ascorbate- linked lipid peroxidation (LPO) with concomitant diminution in enzymatic antioxidative defense systems resulted in decreased glucose residue. The present studies showed some biochemical changes that may be associated with a prolong exposure to electromagnetic fields and its relationship to the activity of antioxidant system in rat Regular assessment and early detection of antioxidative defense system among people working around the base stations are recommended.
\end{abstract}

Keywords: Electromagnetic Field, Telecommunication Base Station, Oxidative Stress, Antioxidant System

\section{Introduction}

Human and animals exposure to environmental hazards from low energy electromagnetic fields (EMF) in several countries showed some compelling evidence of DNA damages of cells in in-vitro cultures when exposed EMF [1-3]. These cells are exposed concurrently or sequentially to multiple electromagnetic fields from variety of sources, including mobile phone base stations [3]. Technological advancement in telecommunication network from point or nonpoint sources is an environmental reality in rural and urban areas [4]. The radiation exposure from these antennas is continuous. Some authors [5] believe that chronic, low-level radiation exposure may, over time be as harmful as higher level radiation. Such effects include Fatigue, headache, sleep disruption and loss of memory [4]. Mobile handsets naturally contribute to athermal influences in living organisms [5], implying a causal relationship in several unspecific symptoms during and after its use [6].

Assessment of potential health risks of EMF are manifested after certain duration of irradiation which indicates long-term cumulative effects. Though, epidemiological studies suggest the existence of weak links between exposure of EMF and human diseases [7] at molecular [8] and cellular levels [9], on immune processes [10], in DNA [11], on the nervous [12], cardiac [13], endocrine [14] reproductive [15] and neurobehavioral effects [16].

Free radical-catalyzed peroxidative damage to membrane lipids may impair the formed elements deformability membrane, $\mathrm{Na}+/ \mathrm{K}+$ gradient and metabolic machinery resulting in decreased ATP level and enzy- me activity [17]. Several ill healths are due to an imbalance between the activities of an oxidant agent and the antioxidant system within the cell. Cytotoxicity is re- 
lated to reactive oxygen species (ROS), viz., superoxide radical $\left({ }^{*} \mathrm{O}_{2}^{-}\right)$, hydrogen peroxide $\left(\mathrm{H}_{2} \mathrm{O}_{2}\right)$, and hydroxyl radical $\left(\mathrm{OH}^{*}\right)$, which are produced by various factors. This link causes oxidative damage to cell membrane, increases in oxygen radical's production and ultimately permits leakage of enzymes, leading to organ damage [18]. The consequences of damage to serum are potentially life-threatening and clinically may manifest as hypoxia and several health disorders. To our knowledge, the effects of repeated exposure to electromagnetic fields at non-thermal intensities level on the oxidative stress in serum are not known.

The aim of the current investigation was to evaluate whether concurrent subchronic exposure to electromagnetic fields at non-thermal intensities at environmentally realistic background concentrations and at a concentration equal to World Health Organization (WHO) maximum permissible limit (MPL)[19] can cause oxidative stress in serum of rats and whether oxidative stress is associated with the concomitant diminution in both enzymatic and nonenzymatic lipid peroxidation as well as antioxidant defense systems.

\section{Materials and Methods}

Male Wistar rats weighing between 75-100 g were procured from the Animal Resource Section, Faculty of Pharmacy, Obafemi Awolowo University, Ile-Ife, Nigeria. They were caged in groups of five in clean plastic container with saw-dust chips for bedding. Animals were maintained under standard management conditions and handled following the guidelines of the Federal Environmental Protection Agency (FEPA). All animals were fed everyday given a standard pellet diet (Ladoke feed, Nigeria Ltd.) and deionized water ad libitum. The animals were kept in the vicinity of the base station ground zero consists of three telecommunication antennas and three shelters which contain electric power generators (electrical field intensity of $2.3 \pm 0.82 \mu \mathrm{V} / \mathrm{m}$ ) and radio-frequencies of 900 or $1800 \mathrm{MHz}$. A model Rados RDS-120 Universal Survey Meter, range 0.05-10 $\mu \mathrm{V} / \mathrm{m}$ ( Rados Tech, Finland) with automatic selection of measuring range was used to measure radiofrequency and microwaves The specific absorption rate (SAR) in the animals range from $0.6 \mu \mathrm{V} / \mathrm{m}$. Comfort 30s Reliable Digital Thermometer (REF 0T11-121c, 070502) was used to measure the temperature around the base stations. The dose-response relationships (non-thermal) are nonlinear [7].

Ten exposed animals were separately kept in the vicinity of base station in non-thermal intensities environment, while ten controlled groups were kept in a similar environment and conditions as the experimental but in nonoperating base station thus served as sham control and ten were housed at a location approximately greater than $300 \mathrm{~m}$ from the nearest designated mobile phone base station.
All animals completed the study. The average exposure time for EMF was $24 \mathrm{~h}$ for forty and/or sixty days.

At $40^{\text {th }}$ day, five exposed five controls and five shams, blood was collected via the tail vein in heparinized tubes and the blood obtained was used for estimation of thiobarbituric acid reactive species (TBARS), reduced glutathione $(\mathrm{GSH})$, catalase activity, glutathione reductase (GR) and residual glucose. At the end of $60^{\text {th }}$ day, animals were treated as previously described.

\section{Measurement of Lipid Peroxidation (LPO)}

Enzymatic and non-enzymatic lipid peroxidation was assessed by measuring malondialdehyde (MDA) levels based on the reaction of MDA with thiobarbituric acid [20]. In brief, $200 \mu \mathrm{l}$ of $30 \%$ blood was incubated at $30 \pm$ $0.5^{\circ} \mathrm{C}$ for $30 \mathrm{~min}$. The sample was mixed with $1 \mathrm{ml}$ of $10 \%$ $\mathrm{w} / \mathrm{v}$ phosphate buffer solution (PBS), and $1 \mathrm{ml}$ of $0.67 \%$ thiobarbiturate in boiling water bath for $10 \mathrm{~min}$. Reaction was initiated by addition of $1 \mu \mathrm{l}$ of NADPH $(1 \mathrm{mM})$ and/ or ascorbate. After cooling, it was diluted with $1 \mathrm{ml}$ distilled water and absorbance was read at $535 \mathrm{~nm}$, Results have been expressed as nmol MDA $/ \mathrm{ml}$. NADPH depended - and ascorbate- linked lipid peroxidation were determined to test the reliability of results (Figure 1).

\section{Assay for GSH Level}

Glutathione content in was estimated following the standard procedure [21]. Briefly, blood (200 $\mu \mathrm{l})$ was mixed with $2.5 \mathrm{ml}$ phosphate buffer $(0.05 \mathrm{M}) \mathrm{pH} 7$ and $200 \mu \mathrm{l}$ of $5,5^{\prime}$ - dithiobis-2-nitro-benzoic acid reagent. Within minutes, absorbance was read at $412 \mathrm{~nm}$. The levels of GSH have been expressed as nmol GSH/ml serum.

\section{Determination of Catalase}

Catalase activity in blood was assayed by the spectrophotometer method [22]. Two hundred microliters were

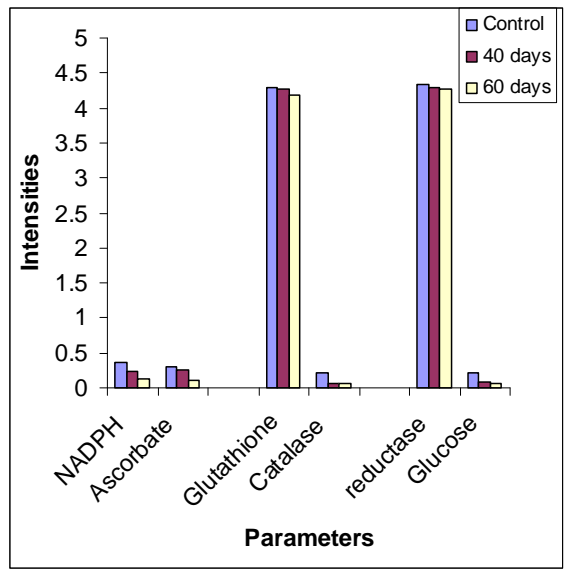

Figure 1. Variations in lipids peroxidation, antioxidative stress and glucose residue 
mixed with phosphate buffer $(50 \mathrm{mM}, \mathrm{pH} 7)$ in a curvette. Reaction was started by adding $1 \mathrm{ml} \mathrm{H}_{2} \mathrm{O}_{2}(10 \mathrm{mM})$ and absorbance was recorded at every $10 \mathrm{sec}$, for $1 \mathrm{~min}$. at $240 \mathrm{~nm}$ against water blank. The activity of catalase has been expressed as $\mathrm{mmol} \mathrm{H}_{2} \mathrm{O}_{2}$ utilized $/ \mathrm{min} / \mathrm{ml}$.

\section{Determination of Glutathione Reductase (GR)}

Glutathione activity was measured following the standard procedure [23]. The $3 \mathrm{ml}$ reaction mixture contained $2.5 \mathrm{ml}$ PBS (0.12 M, pH 7.2), $0.1 \mathrm{ml}$ EDTA (15 mM), and 0.1 oxidized glutathione (GSSG) $(65.3 \mathrm{mM})$. To this, $100 \mu \mathrm{l}$ of blood was added and the volume was made up with $0.15 \mathrm{ml}$ distilled water. After incubation at room temperature for $5 \mathrm{~min}$., $0.05 \mathrm{ml} \mathrm{NADPH}(9.6 \mathrm{mM})$ was added. Decrease in absorbance/min was recorded immediately at $340 \mathrm{~nm}$ for $3 \mathrm{~min}$. Control was run without GSSG. The activity of GR has been expressed as unit $/ \mathrm{ml}$. One unit is $\mu \mathrm{mol}$ NADPH utilized $/ \mathrm{min} / \mathrm{ml}$.

\section{Determination of Residual Glucose}

Residual glucose was determined photometrically [24]. Two hundred microliters of blood mixed with $1 \mathrm{ml}$ of $5 \%$ phenol. Reaction was started by adding $2.5 \mathrm{ml}$ concentrated $\mathrm{H}_{2} \mathrm{So}_{4}$ and absorbance was recorded at $470 \mathrm{~nm}$ after thorough mixing at room temperature for $20 \mathrm{~min}$.
The residual glucose has been expressed as nmol gluco$\mathrm{se} / \mathrm{ml}$.

\section{Statistics}

Statistical analysis: Data were subjected to Barlett's test for homogeneity, followed by analysis of variance (ANOVA). For post hoc comparison Student Newman Keul's test was employed.

\section{Results}

The temperature at the base stations and the power density at the four corners of the base stations are presented in Table 1. Influence of sub chronic exposure to electromagnetic field on various oxidative stress-related parameters in rat whole blood is shown in Table 2. Though they have many and varied outputs, at a distance of $50 \mathrm{~m}$ $\left(C_{1}\right)$ the power density is $0.13 \mu \mathrm{V} / \mathrm{m}$ while at distances of $100 \mathrm{~m}$ at ground level measures $0.69 \mu \mathrm{V} / \mathrm{m}\left(\mathrm{C}_{2}\right)$, between $150 \mathrm{~m}\left(\mathrm{C}_{3}\right)$ and $300 \mathrm{~m}$, the power density range from 0.69 to $0.74 \mu \mathrm{V} / \mathrm{m}$ (Table 1). Results presented demonstrate that the low intensities of electromagnetic fields to rats exposed for forty days failed to induce any significant alterations in any of the oxidative stress-related endpoints in rat. However, at 60 days, exposure duration on the different attributes evaluated for assessing the oxidative stress-inducing potential of electromagnetic field in rat decreased.

Table 1. In-Situ Measurement of Temperature and Radiation emanating from the GSM Base Stations

\begin{tabular}{|c|c|c|c|c|c|}
\hline Point & \multicolumn{2}{|c|}{ Distance (m) } & Temperature $\left({ }^{\circ} \mathrm{C}\right)$ & $\begin{array}{c}\text { Dose Rate } \\
\text { ( } \mu \mathrm{Sv} / \mathrm{hr})\end{array}$ & $\begin{array}{l}\text { Dose } \\
(\mu \mathrm{Sv})\end{array}$ \\
\hline \multirow{4}{*}{$\begin{array}{l}\text { Base Station } 1 \\
\quad(\text { BS 1) }\end{array}$} & Corner $1\left(\mathrm{C}_{1}\right)$ & 0 & 37 & 0.17 & 0.69 \\
\hline & Corner $2\left(\mathrm{C}_{2}\right)$ & 0 & 33.8 & 0.13 & 0.68 \\
\hline & Corner $3\left(\mathrm{C}_{3}\right)$ & 0 & 33.8 & 0.17 & 0.68 \\
\hline & Corner $4\left(\mathrm{C}_{4}\right)$ & 0 & 37 & 0.17 & 0.68 \\
\hline \multirow{4}{*}{$\begin{array}{l}\text { Base Station } 2 \\
\text { (BS 2) }\end{array}$} & Corner $1\left(\mathrm{C}_{1}\right)$ & 0 & 37 & 0.14 & 0.64 \\
\hline & Corner $2\left(\mathrm{C}_{2}\right)$ & 0 & 37 & 0.13 & 0.65 \\
\hline & Corner $3\left(C_{3}\right)$ & 0 & 37 & 0.15 & 0.64 \\
\hline & Corner $4\left(\mathrm{C}_{4}\right)$ & 0 & 37 & 0.11 & 0.64 \\
\hline \multirow{4}{*}{$\begin{array}{l}\text { Base Station } 3 \\
\text { (BS 3) }\end{array}$} & Corner $1\left({ }_{\mathrm{C} 1}\right)$ & 0 & 37 & 0.13 & 0.67 \\
\hline & Corner $2\left(\mathrm{C}_{2}\right)$ & 0 & 37 & 0.16 & 0.66 \\
\hline & Corner $3\left(C_{3}\right)$ & 0 & 37 & 0.15 & 0.66 \\
\hline & Corner $4\left(\mathrm{C}_{4}\right)$ & 0 & 37 & 0.14 & 0.66 \\
\hline \multirow{4}{*}{ BS 1} & \multirow{4}{*}{ From $\mathrm{C}_{1}$ of $\mathrm{BS} 1$} & 50 & 37 & 0.13 & 0.69 \\
\hline & & 150 & 37 & 0.12 & 0.70 \\
\hline & & 200 & 37 & 0.13 & 0.71 \\
\hline & & 300 & 37 & 0.13 & 0.71 \\
\hline \multirow{4}{*}{ BS 2} & \multirow{4}{*}{ From $\mathrm{C}_{2}$ of BS 2} & 50 & 37 & 0.15 & 0.72 \\
\hline & & 150 & 37 & 0.25 & 0.72 \\
\hline & & 200 & 37 & 0.20 & 0.73 \\
\hline & & 300 & 37 & 0.19 & 0.73 \\
\hline \multirow{4}{*}{ BS 3} & \multirow{4}{*}{ From $\mathrm{C}_{2}$ of BS 3} & 50 & 37 & 0.14 & 0.74 \\
\hline & & 150 & 37 & 0.09 & 0.73 \\
\hline & & 200 & $32 *$ & 0.10 & 0.74 \\
\hline & & 300 & 37 & 0.10 & 0.74 \\
\hline
\end{tabular}

*Significantly different $(\mathrm{P}>0.05)$, all rotations are anti-clockwise 
Exposed to Electromagnetic Fields at Non-Thermal Intensities

Table 2. Lipid peroxidation, antioxidative systems and glucose residue in male rats exposed to low level electromagnet fields

\begin{tabular}{|c|c|c|c|c|c|c|}
\hline \multirow{2}{*}{ Treatment } & \multicolumn{2}{|c|}{ Lipid Peroxidation } & \multirow{2}{*}{$\begin{array}{l}\text { Reduced } \\
\text { Glutathione }\end{array}$} & \multirow{2}{*}{ Catalase } & \multirow{2}{*}{$\begin{array}{l}\text { Glutathione } \\
\text { reductase }\end{array}$} & \multirow{2}{*}{$\begin{array}{l}\text { Residual } \\
\text { Glucose }\end{array}$} \\
\hline & NADPH & Ascorbate & & & & \\
\hline Control & $0.373 \pm 0.04$ & $0.300 \pm 0.03$ & $4.30 \pm 0.19$ & $0.209 \pm 0.01$ & $4.34 \pm 0.07$ & $0.209 \pm 0.01$ \\
\hline 40 days & $0.244 \pm 0.01$ & $0.255 \pm 0.05$ & $4.28 \pm 0.17$ & $0.068 \pm 0.01$ & $4.29 \pm 0.00$ & $0.091 \pm 0.01$ \\
\hline 60 days & $0.121 \pm 0.05 *$ & $0.098 \pm 0.020 *$ & $4.19 \pm 0.02$ & $0.055 \pm 0.50^{*}$ & $4.27 \pm 0.18$ & $0.060 \pm 0.12 *$ \\
\hline
\end{tabular}

*Significant $(\mathrm{P}<0.05)$

Errors indicate the standard error of tne mean (SEM), $\mathrm{N}=3$

After 40 days of exposure, there were minor decreases in lipid peroxidations and other parameters except the activity of glutathione reductase which was less marked in comparison to control. At 60 days, the decrease activity of glutathione reductase was $11 \%$ of control, catalase activity decreased by $15 \%$ in comparison to control activity. The energy level showed a significant $(\mathrm{P}<0.05)$ decreased when compared to the control.

After 60 days of exposure of rats to low intensities electromagnetic fields there were decreases in LPO compare to the control group $(\mathrm{P}<0.05)$. Figure 1 shows variations in lipid peroxidation, antioxidative stress and glucose residue. The respective decreases in NADPH dependent and ascorbate linked lipid peroxidation were $25 \%$ and $20 \%$ of the control groups. The ascorbic acid linked lipid peroxidation evidenced by malondialdehyde production was similar to that observed for NADPHlinked lipid peroxidation. The values obtained for NADPHlinked lipid peroxidation were higher than those for ascorbic acid lipid peroxidation.

\section{Discussion}

The present study shows that subchronic exposure to low intensities EMF induced oxidative stress in rat. More importantly, exposure duration further decreased in LPO and other antioxidative defense systems (Table 2). This indicates that prolonged exposure to non-thermal electromagnetic fields may induce several unspecific symptoms as reported by Abdel-Rassoul et al., 2007 and Santini et al., 2003 [16,25]. It is interesting to note that, in quantitative terms ( $\%$ change) the duration of exposure to EMF on all antioxidative attributes was almost similar to control/sham. At 40 and 60 days of exposure, EMF decreased LPO, as well as enzymatic and non-enzymatic antioxidants. The significant decrease in temperature at point $\mathrm{C}_{3}(200 \mathrm{~m})$ from the base station was due to low elevation at water front. Some workers found a variety of self-reported health effects for people living within $1,000 \mathrm{ft}(325 \mathrm{~m})$ of cell towers in rural areas; or within $300 \mathrm{ft}(100 \mathrm{~m})$ of base stations in urban areas $[6,16,26]$. Long-term exposure may imply the development of oxidative stress that commensurate with the advancement of idiopathic symptoms.

Erythrocytes are more vulnerable to LPO [27]. LPO has been shown to cause profound alterations in the structure and functions of the cell membrane, including decreased membrane fluidity, increased membrane-bound enzymes, and loss of essential fatty acids [28]. Several studies in animals and occupationally exposed human subjects indicate that exposure to electromagnetic fields induced mostly sleep disturbance, irritability, depression and headache among others $[1,29,30]$. The steady decrease in LPO in the present study (Table 1) may be attributed to induction of oxidative stress caused by exposure to EMF with diminution in enzymatic antioxidative defense mechanism.

Consistent with these results, reduction in enzymes activities is related to consummations of enzymes in oxidative stress. Inhibition of GR leads to accumulation of the prooxidant GSSG by preventing reduction of GSSG to GSH, suggesting that the depletion of GSH might not have been compensated by GR. Thus, reduced supply of GSH could activate energy utilization, resulting in reduced glucose (Figure 1) [17]. Decreased activity of catalase implies that $\mathrm{H}_{2} \mathrm{O}_{2}$ remains accumulated in the blood. It is known that $\mathrm{O}_{2}$ can spontaneously be converted to $\mathrm{H}_{2} \mathrm{O}_{2}$, therefore, the oxidative stress caused by low intensity electromagnetic fields may be mediated by the conversion of accumulated $\mathrm{H}_{2} \mathrm{O}_{2}$ to $\mathrm{OH}$, which is the ultimate toxicant for conversion to form $\mathrm{O}_{2}$ [31].

The present study of the environmental hazards from low energy EMF exposure demonstrates induction of oxidative stress in rat. Results of this study are associated with concomitant reduction in antioxidant defense systems. The relationship between the levels of exposure in the current study and the actual levels to which the general populations are exposed is relevant to public health. For this reason, the telecommunication industries could take advantage of the complexity of the biological and physical processes to standardize guidelines (exposure distance) to base stations in rural and urban areas. Regular assessment and early detection of antioxidative defense system among people working around the base stations are recommended. 


\section{REFERENCES}

[1] W. R. Adey, "Tissue Interactions with Non-Ionizing Electromagnetic Fields," Physiological Review Vol. 61, No. 2, 1981, pp. 435-514.

[2] N. Nikolaevich, A. Igorevna and G. Vasil, "Influence of High-Frequency Electromagnetic Radiation at Non-Thermal Intensities on the Human Body," No Place to Hide, Vol. 3, No. 1, 2001, pp. 607-613

[3] A. Balmori, "Possible Effects of Electromagnetic Fields from Phone Masts on a Population of White Stork," Electromagnetic Biology and Medicine, Vol. 24, No. 2, 2005, pp. 109-119.

[4] R. Santini, P. Santini, P. Ruz, J. M. Danze and M. seigne, "Survey Study of People Living in the Vicinity of Cellular Phone Base," Journal of Electromagnetic Biology and Medicine, Vol. 22, No. 1, 2002, pp. 41-49.

[5] J. Schũz, E. Bôhler, G. Berg, B. Schlehofer, I. Hettinger, K. Schlaefer. J. wahrendorf, K. Kunna-Grass and M. Blettner, "Cellular Phones, Cordless Phones and the Risks of Glioma and Meningioma," (Interphone study Group, Germany). American Journal of Epidemiology, Vol. 163, No. 6, 2006, pp. 512-520.

[6] A. Auvinen, K. G. Blaasaas, E. Cardis, H. C. Christensen, M. Feychting, S. J. Hepworth, C. Johansen, L. Klaeboe, S. Lonn, P. A. McKinney, K. Muir, J. Ra-tanen, T. Salminen, J. Thomsen and T. Tynes, "Mobile Phone Use and Risk of Acoustic Neuroma; Results of the Interphone CaseControl Study in 5 North European Countries," British Journal of Cancer 3, Vol. 93, No. 7, 2005, pp. 842-848.

[7] A. A. Marino, E. Nilsen and C. Frilot, "Non-Linear ChaNges in Brain Electrical Activity Due to Cell Phone Radiation," Bioelectromagnetics, Vol. 24, No. 5, 2003, pp. 339-346.

[8] C. Daniells, I. Duce, D. Thomas, P. Sewell, J. Tattersall and D. De Pomerai, "Transgenic Nematodes as Biomonitors of Microwave-Induced Stress," Mutation Research, Vol. 399, No. 1, 1998, pp. 55-64.

[9] S. K. Dutta, B. Ghosh and C. F. Blackman, "Radiofrequency Radiation-Induced Calcium Ion Efflux Enhancement from Human and Other Neuroblastoma Cells in Culture," Bioelectromagnetics, Vol. 10, No. 2, 1989, pp. 197-202.

[10] K. I. Obukhan, "The Effects of Ultrahigh-Frequency Radiation on Adaptation Thresholds and the Damages to Blood System Cells," Lik Sprava, Vol. 2, No. 7, 1998, pp. 71-73

[11] S. Sarkar, S. Ali and J. Behari, "Effect of Low Power Microwave on the Mouse Genome: A Direct DNA Analysis," Mutation Research, Vol. 320, No. 1-2, 1994, pp. 141-147.

[12] S. Lônn, A. Ahlbom, P. Hall and M. Feychting, "LongTerm Mobile Phone Use and Brain Tumor Risk," American Journal of Epidemiology, Vol. 161 No. 6, 2005, pp. 526-535.

[13] T. E. Belousova and R. A. Karginat-Terent'eva, "Adrenergic Nerve Plexuses of Heart and Adrenal and Myocar- dial Catecholamines of Spontaneously Hypertensive Rats Under the Influence of Electro-Magnetic Irradiation in the Millimeter Range,” Morfologia, Vol. 115, No. 1, 1999, pp. 16-18.

[14] M. Petrides, "Exposure to Electromagnetic Fields by Using Cellular Telephones and its Influence on the Brain," Neuro Report, Vol. 11, No. 15, 2000, p. F15.

[15] K. J. Fernie, D. M. Bird, R. D. Dawson and P. C. Lague, "Effects of Electromagnetic Fields on the Reproductive Success of American Kestrels," Journal of Physiology, Biochemical and Zoology, Vol. 73, No. 1, 2000, pp. 60-65.

[16] G. Abdel-Rassoul, O. Abou EL-Fateh, M. Abou Salam, A. Michael, F. Farahat, M. EL-Batanouny and E. Salem, "Neurobehavioral Effects among Inhabitants around Mobile Phone Base Stations," Neuro Toxicology, Vol. 28, No. 2, 2007, pp. 434-440.

[17] B. Tavazzi, D. Pierro, A. M. Amorini, et al, "Energy Metabolism and Lipid Peroxidation of Human Erythrocytes as a Function of Increased Oxidative Stress," European Journal of Biochemistry, Vol. 267, No. 3, 2000, pp. 684 689.

[18] J. Everse and N. Hsia, "The Toxicities of Native and Modified Hemoglobins," Free Radiological Biology and Medicine, Vol. 22, No. 6, 1997, pp. 1075-1099.

[19] M. Havas, "Dirty Electricity Elevates Blood Sugar among Electrically Sensitive Diabetics and May Explain Brittle Diabetes," Electromagnetic Biology and Medicine, Vol. 27, No. 2, 2008, pp. 135-146.

[20] M. Younnes and C. P. Siegers, "Lipid Peroxidation as a Consequence of Glutathione Depletion in Rat and Mouse Liver," Research of Common Chemical Pathology and Pharmacology, Vol. 27, No. 1, 1980, pp. 119-128.

[21] H. K. Prins and J. A. Loos "Glutathione," In: J. G. Yunis, Ed., Biochemical Methods in Red Cell Genetics, Academic Press, New York, 1969, pp. 127-129.

[22] H. E. Aebi, "Catalase," In: H. U. Bergmeyer, J. Bergmeyer, and M. GraBL, Ed., Methods of Enzymatic Analysis, Verlag Chemie, Weinheim, 1983, pp. 273-286.

[23] D. M. Goldberg and R. J. Spooner, "Glutathione Reductase," In: H. U. Bergmeyer, J. Bergmeyer and M. GraBL, Eds., Methods of Enzymatic Analysis, Verlag Chemie, Wenham, 1983, pp. 258-265.

[24] N. A. Nelson, "Photometric Adaptation of Somogy Method for the Determination of Glucose," Journal of Biological Chemistry, Vol. 153, No. 1, 1944, pp. 375-380.

[25] R. Santini, P. Santini, J. M. Danze, P. Le Ruz and M. Seigne, "Symptoms Experienced By People in Vicinity of Base Stations: II/Incidences of Age, Duration of Exposure, Location of Subjects in Relation to the Antennas and Other Electromagnet Factors," Journal of Pathology and Biology, Vol. 51, No. 7, 2003, pp. 412-415.

[26] R. Santini, P. Santini, J. M. Danze, P. Le Ruz and M. Seigne, "Study of the Health of People Living in the Vicinity of Mobile Phone Base Stations: 1. Influence of Distance and Sex," Journal of Pathology and Biology, Vol. 50, No. 4, 2005, pp. 369-373. 
[27] J. Eritsland, "Safety Considerations of Polyunsaturated Fatty Acids," American Journal of Clinical Nutrition, Vol. 71, No. 1, 2000, pp. 1975-1980.

[28] G. Van Ginkel and A. Sevanian, "Lipid Peroxidation-Induced Membrane Structural Alterations," Methods Enzymol, Vol. 233, No. 2, 1994, pp. 273-288.

[29] G. Hyland, "Physics and Biology of Mobile Telephony," Lancet, Vol. 356, No. 12, 2005, pp. 1833-1836.

[30] M. Rôôsli, M. Moser, Y. Baldinini, M. Meier and C. B.
Fahrlander, "Symptoms of Ill Health Ascribed to Electromagnetic Field Exposure-A Questionnaire Survey International," Journal of Hygiene and Environmental Health, Vol. 207, No. 2, 2004, pp. 141-159.

[31] Z. Gregus and C. D. Klaassen, "Mechanism of Toxicity," In: C. D. Klaassen, Ed., Casarett and Doull's Toxicology: The Basic Science of Poisons, McGraw-Hill, New York, 2001, pp. 35-81. 